\title{
韓国の一山新都市における未利用敷地の菜園利用の 意味と役割
}

The Meaning and Role of Vegetable Gardens on Unused Sites in Ilsan New Town Near Seoul in Korea

金 永敏* 澤木昌典* 鳴海邦碩 ${ }^{*}$ 金 益煥**

Yungmin KIM, Masanori SAWAKI, Kunihiro NARUMI, Ickhwan KIM

摘要 : 韓国ソウル周辺のニュータウンである一山新都市の内部に分布している未利用敷地の大部分は, 近隣住民に菜園として私的利用されている。本研究は，この菜園利用者に対するヒアリング調查を行 い, 未利用敷地における菜園の意味と役割を明らかにすることと今後のニュータウン開発における農 地の整備可能性を示唆することを目的とする。調査結果から, 未利用敷地の菜園利用は, 実利型の菜 園の役割と共に, 健康及び休食的な側面, 心理・社交的側面において居住者の生活に様々な影響を与 えていることが明らかになった。また利用者には住宅地内への小規模な菜園整備への要求が強いため,

韓国のニュータウンでは，菜園整備の必要性があると考えられる。

\section{1.はじめに}

韓国の首都ソウルの周辺には，深刻な住宅問題の解消のために 1980 年代末から開発された 5 つのニュータウンが立地している。

これらのニュータウンの一つである一山新都市の中には, 2001 年現在, まだ未利用のままで放置されている敷地が数多く分布し ている。この未利用敷地のほとんどは, 近隣の居住者に勝手に菜 園として利用されている状況である。このような未利用敷地の菜 園の利用は，一山新都市だけではなく，他のニュータウンでも同 様に行われている。

これら未利用敷地の菜園利用は, 一山新都市で入居が始まった 1992 年から現在まで継続しているが，これは，1990 年代の韓国 で都市居住者の関心を集めて始まった大都市周辺の「市民農園」と は全く異なる形態の農地である。

なお，このように現在まで菜園利用が持続している未利用敷地 は，あくまでも建築予定地であるため，その菜園利用の実態を明 らかにすることによって, 今後のニュータウンの居住環境整備に おける菜園の意味之役割などについて考察する必要があると考え られる。

関連する既往研究としては, 韓国の市民農園の利用実態や利用 者の評価に対する研究 ${ }^{122}$ が行われているが、ニュータウンの未利 用敷地の菜園利用に関する研究はまだ行われていない。

そこで, 本研究は, 一山新都市の未利用敷地で行われている菜 園利用者にヒアリング調査を行い, ニュータウン内の菜園利用の 実態，そしてその意味と役割を明らかにし，都市部の市民農園利 用と比較考察することと, 今後のニュータゥン開発における菜園 の整備の可能性などを考察することを目的とする。

\section{2. 調查の方法と調查対象}

\section{（1）調查方法之調查対象者の属性}

本研究では, 未利用敷地で行われている菜園利用の意味之役割, 及び将来への希望などの内面的な要素を調査するために, 菜園利 用者を対象としてヒアリング調査を行った。調查期間は，2001 年 8 月 9 日から 8 月 30 日までである。調査対象は 20 人である。 なお，これは利用者が任意に敷地を占用しているため, 利用者の 住所の把握が困難であり, また利用者の作業時間帯が短く, 接触 することが困難であったためである。

主な調査項目は,「農作物を植えた理由・動機」,「場所を選択
した理由」,「地主・近隣住民・他の利用者とのかかわり」,「管理 の状況」,「都市内の農地整備についての意見」などである。

調査対象者の属性は，男性 5 人，女性 15 人，年齢層は 60 代以 上 11 人, 50 代 7 人, 40 代以下 2 人である。職業については, 女 性の全員は専業主婦であり, 男性は一人の勤め人を除外するとそ のほかは無職であった。

\section{(2) 一山新都市の概要}

調查対象地である一山新都市は, 首都ソウルの住宅難解消のた

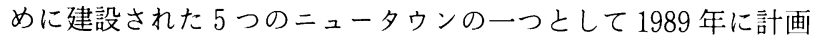
され，1992 年に第一次の入居が開始された。ソウルの北西約 20 $\mathrm{km}$ に位置し, 面積は $1,573.6 \mathrm{ha}$, 人口は 27.8 万人である。計画戸

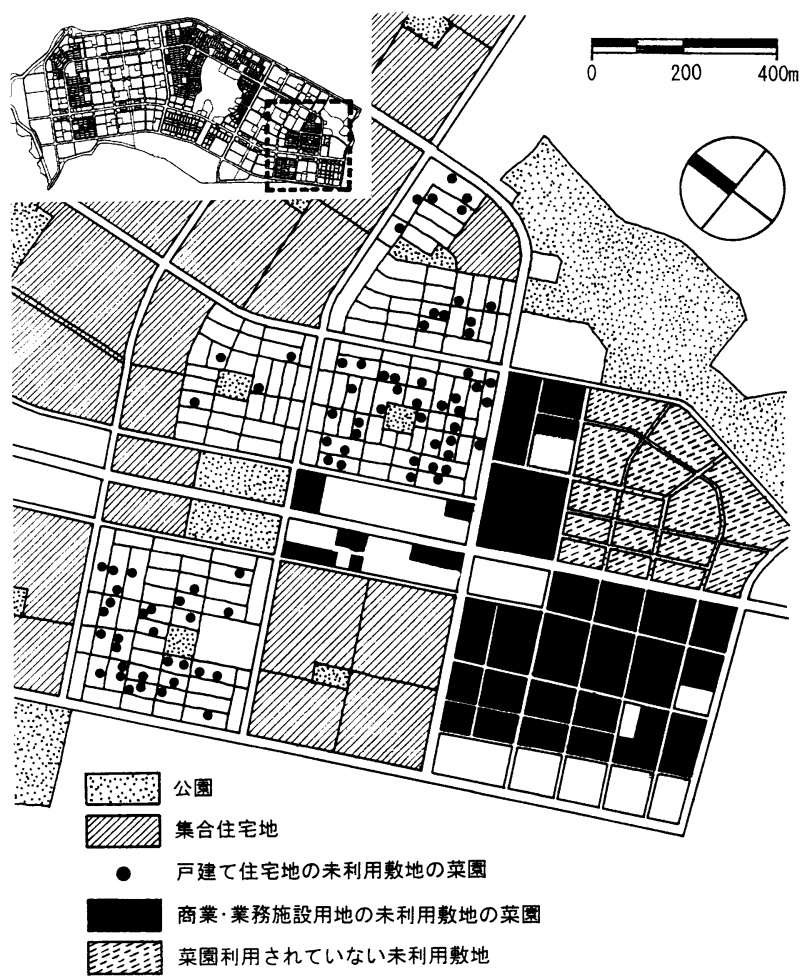

図－1 一山新都市の白石洞一帯に分布している未利用敷地の菜園

*大阪大学大学院工学研究科 **韓国金烏工科大学校土木・環境及び建築工学部 


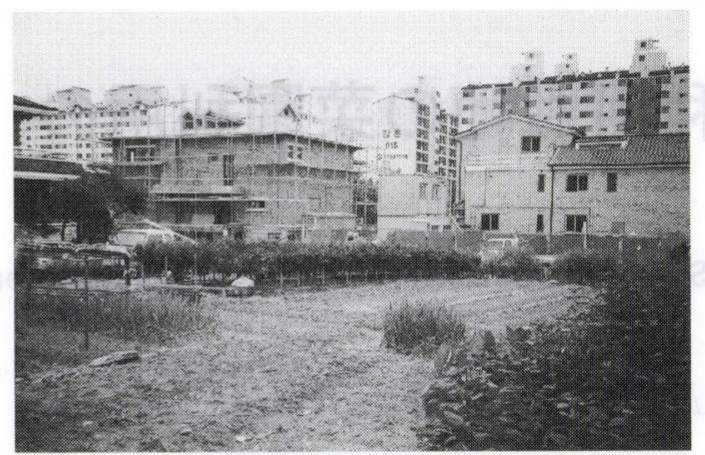

戸建て住宅地の未利用敷地の菜園

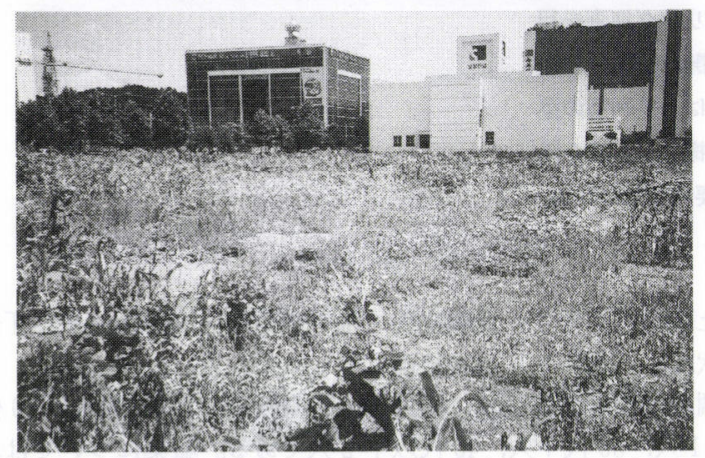

商業・業務施設用地の未利用敷地の菜園

写真-1 一山新都市の未利用敷地の菜園利用
数は 69,000戸で, 内訳は中高層集合住宅 58,008 戸 (84.1\%), 中 低層連棟型集合住宅 5,122 戸(7.4\%), 戸建て住宅 5,870 戸 (8.5\%) である。

一山新都市の土地利用比率は，住宅建設用地 $33.5 \%$, 商業 • 業務施設用地 $7.8 \%$, 公共施設用地 $58.7 \%$ となっている。公共施 設用地のうち, 公園・緑地は $23.1 \%$ (全体面積比)を占めている。

\section{3. 調査結果}

（1）対象とした未利用敷地の状況

一山新都市の住宅用地の内, 中高層集合住宅地以外の戸建て住 宅地や中低層連棟型集合住宅地，及び商業・業務施設用地には， まだ未利用のままで放置されている敷地が多い。この未利用敷地 の大部分は, 近隣住民の任意的占用によって菜園として私的に利 用されている。図ー 1 は, 一山新都市の白石洞一帯の住宅地と商 業・業務施設用地に分布している未利用敷地の菜園を表したもの であり, 写真 -1 は, 未利用敷地の菜園の写真である。このよう な菜園利用は, 一山新都市の全域に同じ様子で数多く分布してお り，首都圏の他のニュータウンであ同様の状況である。

未利用敷地の菜園は, 利用者 1 人あたり $10 \sim 30 \mathrm{~m}^{2}$ 程度に分け られて, 主に白菜, 大根, ネギ, 唐辛子, エゴマ, チシャ, 豆, ジャガイモ, カボチャなど, 韓国人が日常食する野菜が植えられ ている。農機具を保管する倉庫, 日陰を作る簡単な休秝施設など の設備む稀にはあるが, 大部分は, 農作物だけが植えられている。

この未利用敷地の所有者は, 個人, 土地公社, 民間の建設会社 及び民間デベロッパーなどである。

表 - 1 菜園利用の理由と動機

\begin{tabular}{|c|c|c|c|c|c|c|c|c|c|c|}
\hline 回答者 & 農作物を植えた理由 & 始めたきっかけ & 場所選択の理由 & 性別 & 年齢層 & 職業 & 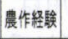 & 出身地 & 本来の土地利用 & 所有形態 \\
\hline 1 & $\begin{array}{l}\text { 食用. 収穫物を知り合いに分け } \\
\text { る喜び }\end{array}$ & 自発的 $*$ & 家から近い & 男 & 60 代 & 無 & 無 & 農村 & $\begin{array}{l}\text { 公共用地 } \\
\text { (文化施設) }\end{array}$ & 市有地 \\
\hline 2 & 無農薬，収穫の喜び & 自発的 & 家から近い & 男 & 60 代 & 勤め人 & 無 & 大都市 & 商業·業務施設用地 & 民有地 \\
\hline 3 & $\begin{array}{l}\text { 食用，作物が育つ過程の神秘さ， } \\
\text { 収權の喜び }\end{array}$ & $\begin{array}{l}\text { 老人達が農作しているのを } \\
\text { みて自分もやりたくなっ } \\
\text { た。 }\end{array}$ & 家から近い & 女 & 40 代 & 専業主婦 & 無 & 大都市 & 商業·業務施設用地 & 民有地 \\
\hline 4 & $\begin{array}{l}\text { 食用，収穫物を知り合いに分ける } \\
\text { 喜ひ }\end{array}$ & 自発的 $*$ & 家から近い & 女 & 60 代 & 専業主婦 & 有 & 農村 & $\begin{array}{l}\text { 公共用地 } \\
\text { (文化施設) }\end{array}$ & 市有地 \\
\hline 5 & 食用，無農薬 & $\begin{array}{l}\text { 自発的（無農薬がほしく } \\
\text { て） }\end{array}$ & $\begin{array}{l}\text { 家の近い所には空地がないの } \\
\text { で、空地を探してここまで }\end{array}$ & 女 & 60 代 & 専業主婦 & 有 & 農村 & $\begin{array}{l}\text { 公共用地 } \\
\text { (文化施設) }\end{array}$ & 市有地 \\
\hline 6 & 食用，無農薬，健康にいい(運動) & $\begin{array}{l}\text { 自発的*（空地を見つける } \\
\text { と、植物を植えたい） }\end{array}$ & $\begin{array}{l}\text { 空地があれば、どこでもやりた } \\
\text { い。もう、3ヶ所やっている。 }\end{array}$ & 男 & 60 代 & 無 & 無 & ソウル & 商業·業務施設用地 & 民有地 \\
\hline 7 & 食用, & 自発的* & 家から近い & 女 & 50 代 & 専業主婦 & 無 & ソウル & 商業·業務施設用地 & 民有地 \\
\hline 8 & 食用. & 自発的 * & 家から近い & 女 & 60 代 & 専業主婦 & 無 & 小都市 & 商業·業務施設用地 & 民有地 \\
\hline 9 & $\begin{array}{l}\text { 食用、健康にいい(運動)，作物が } \\
\text { 育つ過程の神秘さ、余暇活用 }\end{array}$ & $\begin{array}{l}\text { 自発的（退屈生活から脱 } \\
\text { 皮） }\end{array}$ & 家から近い & 女 & 50代 & 専業主婦 & 無 & 大都市 & 商業·業務施設用地 & 民有地 \\
\hline 10 & $\begin{array}{l}\text { 食用，作物が育つ過程の神秘さ, } \\
\text { 收種物を知り合いに分ける喜び } \\
\end{array}$ & 自発的 & 他の空き地より土質が良い。 & 女 & 50 代 & 専業主婦 & 無 & 農村 & 商業·業務施設用地 & 民有地 \\
\hline 11 & 余睱活用，健康にいい(運動) & 自発的 * & 家から近い & 男 & 60 代 & 無 & 無 & 大都市 & 戸建て住宅用地 & 民有地 \\
\hline 12 & 土と植物とのふれあい & 自発的* & 家から近い & 女 & 50代 & 専業主婦 & 無 & 大都市 & 商業·業務施設用地 & 民有地 \\
\hline 13 & 健康にいい(運動) & 他人に言われて & 家から近い & 女 & 60 代 & 専業主腣 & 無 & 小都市 & 戸建て住宅用地 & 民有地 \\
\hline 14 & 余睱活用 & 自発的 * & 家から近い & 男 & 60代 & 無 & 無 & ソウル & 戸建て住宅用地 & 民有地 \\
\hline 15 & $\begin{array}{l}\text { 健康にいい(運動)，精神の健康に } \\
\text { いい、収㯳物を知り合いに分け } \\
\text { る喜ひ、、学衝の神聖性 }\end{array}$ & 自発的 & & 女 & 60 代 & 専業主婦 & 無 & 農村 & $\begin{array}{l}\text { 公共用地 } \\
\text { (文化施設) }\end{array}$ & 市有地 \\
\hline 16 & $\begin{array}{l}\text { 健康にいい(運動)，労働の神聖 } \\
\text { 性、こどもの教育 }\end{array}$ & 自発的 & 家から近い & 女 & 50代 & 専業主㛿 & 無 & 大都市 & 商業·業務施設用地 & 民有地 \\
\hline 17 & $\begin{array}{l}\text { 作物が育つ過程の神秘さ，収穫物 } \\
\text { を知り合いに分けるる喜び }\end{array}$ & $\begin{array}{l}\text { 自発的*（空き地を見つけ } \\
\text { ると、植物を植えたい） }\end{array}$ & $\begin{array}{l}\text { 家の近い所には空地がないの } \\
\text { で、空地を探してここまで }\end{array}$ & 女 & 50 代 & 専業主婦 & 無 & ソウル & $\begin{array}{l}\text { 公共用地 } \\
\text { (文化施設) }\end{array}$ & 市有地 \\
\hline 18 & 食用，作物が育つ過程の神秘さ & $\begin{array}{l}\text { 自発的（無聊な生活から脱 } \\
\text { 皮） }\end{array}$ & $\begin{array}{l}\text { 家の近い所には空地がないの } \\
\text { で、空地を探してここまで }\end{array}$ & 女 & 60 代 & 専業主婦 & 無 & 農村 & $\begin{array}{l}\text { 公共用地 } \\
\text { (文化施設) }\end{array}$ & 市有地 \\
\hline 19 & $\begin{array}{l}\text { 食用、土と植物とのふれあい, 余 } \\
\text { 暇活用，精神の健康にいい，作物 } \\
\text { が㕕つ過程の神秘さ } \\
\end{array}$ & $\begin{array}{l}\text { 他人がしているのを見て、 } \\
\text { 自分もやりたくなって }\end{array}$ & 家から近い & 女 & 50 代 & 専業主婦 & 無 & 小都市 & 戸建て住宅用地 & 民有地 \\
\hline 20 & $\begin{array}{l}\text { 食用，こどもの教育，土と植物と } \\
\text { のふれあい，余暇活用，収穫の喜 } \\
\text { び } \\
\end{array}$ & $\begin{array}{l}\text { 他人がしているのを見て、 } \\
\text { 自分もやりたくなって }\end{array}$ & $\begin{array}{l}\text { 空地がなかったので、となりの } \\
\text { 人から少しもらった。 }\end{array}$ & 女 & 30 代 & 専業主婦 & 無 & 大都市 & 戸建て住宅用地 & 民有地 \\
\hline
\end{tabular}

(注) : 番号をハッチングした回答者は、図ー1に示した「白石洞一帯」以外の未利用敷地における回答者である。 


\section{（2）菜園利用の理由と動模}

表ー 1 は, 菜園利用の理由と動機などを簡略に整理したもので ある。

農作物を植えた理由については，「食用のため」（12人）が一 番多く,「健康にいい（運動）」（6 人), 「余暇の活用」（6 人), 「収穫物を知り合いに分ける喜び」（6 人), 「作物が育つ過程の神 秘さ」（ 5 人）の順である。「食用のため」が共通の回答として一 番多かったが, 各々の回答者はそれ以外の理由をさらに強調する 傾向があった。

始めたきっかけは，自発的に始めた人が 16 人で大部分を占め ている。その具体的な動機としては,「近い所に土地が遊んでい るため(表一 1 では*印で表す。)」と簡単に述べた利用者が多い。 これは，「空地に農作物を植えるのはあたりまえではないか」ま たは,「遊んでいる土地を見つけると, 農作物を植えたい」とい う土地に対する韓国人の考え方の現れであると考えられる。

場所を選択した理由は，「家から近い」(13人) が一番多く, 近い距離に立地することが菜園利用の重要な動機になっているこ とがわかる。

また，利用者の農作業の経験と故郷などをたずねた結果，8割 の利用者が都市生活者であり, 農作業の経験むなかった。菜園利 用の動機と農作業経験とはあまり関係ないと考えられる。

以上の結果をみると，一山新都市の未利用敷地の菜園利用は, 実利型の菜園の役割とともに, 高年齢層の身体及び精神的な健康 を維持する「健康及び休養的側面」, 収穫の喜び・作物が育つこ

表 -2 菜園利用者間のコミュニケーション

\begin{tabular}{|c|c|c|c|}
\hline 回警者 & 利用者間のコミュニケーション & 回答者 & 利用者間のコミュニケーション \\
\hline 1 & 豊作業の指導を受ける & 11 & 収萎物交換，農作業の情報交換 \\
\hline 2 & 収穫物交換，農作業の情報交換 & 12 & 收穫物交換 \\
\hline 3 & 農作莱の指遵を受ける & 13 & \\
\hline 4. & 他人の農作業を手伝う & 14 & 收檴物交換 \\
\hline 5 & 談笑 & 15 & $\begin{array}{l}\text { 收稪物交換. } \\
\text { 他人の農作業を手伝う }\end{array}$ \\
\hline 6 & 談笑 & 16 & $\begin{array}{l}\text { 談笑, 喱作業の情報交換. } \\
\text { 收權物交換 }\end{array}$ \\
\hline 7 & & 17 & 談笑 \\
\hline 8 & 談笑，農作業の指道を受ける & 18 & 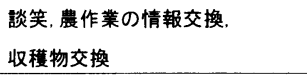 \\
\hline 9 & 談笑 & 19 & 農作業の情報交換 \\
\hline 10 & $\begin{array}{l}\text { 農作業の指䆃を受ける。 } \\
\text { 収䅗物交換 }\end{array}$ & 20 & 農作業の指溥を受ける \\
\hline
\end{tabular}

(注)：番号をハッチングした回答者は、图ー1にに示した「白石洞一带」以外の未利用 數地における回答者である。

表 -3 菜園の管理頻度と自宅からの距離

\begin{tabular}{|c|c|c|c|c|c|}
\hline 回答者 & 管理頻度 & 自宅からの距離 (m) & 回答者 & 管理類度 & 自宅からの距醉 (m) \\
\hline 1 & 週 3-4回 & 500 & 11 & 毎日 & 50 \\
\hline 2 & 週 1-2回 & 1000 & 12 & 週 1-2回 & 200 \\
\hline 3 & 週 1-2回 & 100 & 13 & 毎日 & 10 \\
\hline 4 & 䓢 1 回 & ソウル & 14 & 毎日 & 50 \\
\hline 5 & 毎日 & 1000 & 15 & 毎日 & 6000 \\
\hline 6 & 週 3-4 回 & 300 & 16 & 毎日 & 500 \\
\hline 7 & 毎日 & 50 & 17 & 䓢 1 回 & 5000 \\
\hline 8 & 毎日 & 50 & 18 & 䓢 1-2回 & 2500 \\
\hline 9 & 毎日 & 100 & 19 & 毎日 & 50 \\
\hline 10 & 週 $1-2$ 回 & 250 & 20 & 毎日 & 100 \\
\hline
\end{tabular}

(注)：番号をハッチングした回答者は、图一1に示した「白石洞一帯」以外の未利用 敷地における回答者である。
との神秘などの「心理的側面」，収穫物を知り合いに分配する喜 びなどの「社交的側面」として, 菜園利用者の生活に様々な好影響 を与えていることが明らかになった。

（3）菜園利用におけるコミュニケーション

次に, 地主・近隣居住者・他の菜園利用者とのかかわりについ て述べる。

すべての回答者が，地主とは何ら契約を結んでいなかった。9 割以上の回答者（19人）が地主と会ったこともないし，どのよ うな制約もないと述べた。このように地主とのトラブルが発生し ないのは，地主之利用者の相互に菜園利用は恒久的なものではな く，地主が本来の土地利用を実現する場合には，すぐに土地を原 状に復すことができるという認識を有しているためと推察される。

さらに，近隣住宅地の居住者からの不満や制約などあなく，ほ とんどの利用者が，作物を自宅の近隣居住者に分配した経験があ り, 近隣とのコミュニケーション形成の一助むなしていることが わかる。

表一 2 は，菜園利用者が互いに行っているコミュニケーション についてたずねた結果である。ほとんどの利用者が，他の利用者 と「農作業情報の交換」,「収穫物の交換」「談笑」などのコミュ ニケーションを行っていることがわかる。また，菜園利用におけ る利用者間の規則（ルール）としては，「土地を先に占用した人 が，その土地を使用する権利を持つ」と「他人の農作物を毁損し ない」ということが暗黙的に認められていることがわかる。

\section{（4）菜園の管理}

表一 3 は, 利用者の菜園管理頻度と自宅からの距離について整 理したあのである。

毎日管理している利用者が，5割以上（11 人）を占めている。 調査期間が 8 月の蒸し暑い夏であったにもかかわらず毎日管理す る人が多いのは, 自宅からの距離と密接な相関関係があると考え られる。

また，農作業に必要な農機具や水などあ自宅から持って来る場 合が，9割（18人）と多いことも明らかになった。

未利用敷地の菜園利用は，自宅から近い距離に位置している利

\begin{tabular}{|c|c|c|c|}
\hline 回答者 & 計画的に整備する農地の位置 & 希望面積/人 & 支払金額/年 \\
\hline 1 & $\begin{array}{l}\text { 住宅地の周辺の適当な距離 } \\
\text { (管理人不要) }\end{array}$ & 100 坪 & 30万ウォン \\
\hline 2 & 都市の中に大規模（管理人不要） & 100 坪 & 10万ウォン \\
\hline 3 & 都市の中に大規模 & 20-30 坪 & \\
\hline 4 & 住宅地の中に小規模 & 30 坪 & 3万ウォン \\
\hline 5 & 住宅地の周辺（自転車の利用距離） & 10 坪 & 10万ウォン \\
\hline 6 & 住宅地の中に小規模 & 200 坪 & \\
\hline 7 & 住宅地の中に小規模 & $100-200$ 坪 & 10万ウォン \\
\hline 8 & 住宅地の中に小規模 & & \\
\hline 9 & 住宅地の中に小規模 & 100 坪 & 5万ウォン \\
\hline 10 & 住宅地の中に小規模 & 100 坪 & 5万ウォン \\
\hline 11 & 住宅地の中に小規模 & 30 坪 & 適当に \\
\hline 12 & 住宅地の中に小規模 & 20 坪 & 10万ウォン \\
\hline 13 & 要らない (空地で十分) & & \\
\hline 14 & 住宅地の中に小規模 & 10 坪 & 費用不問 \\
\hline 15 & 住宅地の中に小規模 & 70 坪 & 5万ウォン \\
\hline 16 & 場所不問 & 50 坪 & 適当に \\
\hline 17 & 住宅地の中に小規模 & 100 坪 & 5万ウォン \\
\hline 18 & 住宅地の中に小規模 & 200-300 坪 & 10万ウォン \\
\hline 19 & 住宅地の中に小規模 & 50 坪 & 10万ウォン \\
\hline 20 & $\begin{array}{l}\text { 住宅地の中に小規模, } \\
\text { アパート団地の中 }\end{array}$ & 10 坪 & 5万ウォン \\
\hline
\end{tabular}

（注）：番号をハッチングした回答者は、図ー1に示した「白石洞一帯」以外の未利用 敷地における回答者である。 
点を十分に生かして, 農作物の管理の頻度も高く, 特別な施設に 頼らなくても可能であるという特徴を持っていることが明らかに なった。

\section{（5）将来の農地整備についての要求}

表一 4 は, 今後のニュータウン開発における菜園の計画的な整 備についての利用者の意向を整理したものである。

まず，ニュータウン内に菜園を計画的に整備することには，9 割以上の利用者 (19人) が, 積極的に賛成していることが明ら かになった。この中の 17 人は, 特に希望する場所として, 住宅 地の中に小規模で整備することを希望したが, 一部の利用者 (2 人）は，堆肥のにおいが近隣住民の迷惑になることから，住宅地 の中ではなく周辺の近い場所を希望していた。

希望する面積は, 50 坪 $\left(166 \mathrm{~m}^{2}\right)$ 以下または, 100 坪 $\left(332 \mathrm{~m}^{2}\right)$ 以上に二分されている。これは, 現状では利用者が競って菜園を 占有しているので, 大規模な面積を確保することは困難であるが, 冬季の保存用キム千作りや収穫物を遠くに住んでいる親族に送っ たりするために 100 坪以上の面積を希望する利用者も多いためと 推察される。

また，費用の支払いについては，ほとんどの利用者が費用を払 う用意があり，その金額は 1 年で 5 万〜 10 万ウォン（日本円で 約 5 千〜 1 万円）〈゙らいである。費用を支払う条件としては, 「無期限の農作を保証すること」を挙げた利用者が 12 人と多かっ た。

必要な施設については，多くの利用者からはとくに要求がなかっ たが, 一部の利用者（4 人）には日陰のある休鄎施設・倉庫・給 水施設への要求があった。

以上より, ニュータゥン内での農地の整備に関しては, 自宅か ら近い距離の住宅地内の小規模な菜園整備に対して, 大部分の利 用者が費用を支払う用意があるなど, 強い要求を有していること が明らかになった。

\section{4. まとめと考察}

本研究では，たとえ不法な行為にもかかわらず一山新都市の未 利用敷地に曼延している近隣居住者による私的菜園利用について, その意味と役割について明らかにした。その結果を通して, 次の ことが言える。

未利用敷地での菜園利用の特徵は, 主に近隣居住者による任意 の利用で, 地主との契約はないが，地主や近隣居住者からの制約
あなく, 暗黙的に認められている行為であることが明らかになっ た。また， 50 代以上の高年齢層の専業主婦や無職者を中心とし て, 近距離の居住者により日常的に利用されている実態が明らか になった。

このような菜園利用は, 食用などの実利型の菜園の役割ととも に, 都市居住者の生活において, 高年齢層の身体的・精神的な健 康を維持する「健康及び休養的側面」, 収穫の喜び・作物が育つ ことの神秘さを感じるなどの「心理的側面」, 収穫物を知り合い におすそ分けする喜びなどの「社交的側面」として，好影響を与 えていることが明らかになった。

ここで, 都市部の市民農園と比較考察すると, 盧らの研究 ${ }^{3}$ に よると, 都市部の市民農園には所有者との契約があり，有料で管 理者がいること，利用者も 30〜 40 代が中心となっており，「子女 の教育や農村への好奇心と体験」「家族と一緒にする週末休息」, 「農村やふるさとに対する郷愁」などが利用要因として挙げられ ることなどの点で, 本研究の対象としたニュータウンの未利用敷 地の菜園利用とは異なっている。

このように未利用敷地の菜園利用は市民農園に比べて, 利用者 の日常生活とより密接にかかわっている菜園であるといえる。

また，未利用敷地の菜園利用は，自宅での近隣関係や他の利用 者とのコミュニケーションに関しても好影響を与えていることが 明らかになった。末利用敷地の菜園利用は地域コミュニティ及び 近隣居住者とのコミュニケーション形成にも一助をなしており, ニュータウンでの菜園整備は, 今後社会的にも大きな意味をむっ てくると考えられるとともに，今後の高齢化社会の到来や持続可 能な社会の形成といった観点からも，重要な生活様式の一つであ ると評価できる。

ニュータゥン内に菜園を整備していくことに関しては，住宅地 内での小規模な菜園整備への要求が強いことを考えれば，今後,

韓国でニュータゥンを開発する際には，計画の段階から小生活圏 ごとに小規模な菜園を整備することを検討する必要性があり，ま た，既存のニュータゥンや大都市でも，公共の遊休地などを菜園 として活用する方策を検討することが望ましいと考えられる。

最後に, 本研究では, 菜園利用者のみを対象として菜園の意味 や役割を明らかにしたが，今後，ニュータウンの一般居住者を対 象として未利用敷地の全般的な評価を行っていくことを課題とし たい。

\section{参考文献}

1 ）盧庚兒・金裕逸（1995)：市民農園の 利用動機と満足度に関する研究：韓国
造園学会誌 Vol.22 No.4, 133-148

2) イ・ウンヒ, キム・ヨンア (1998) :

週末農場の利用実態の分析ーソウル市
内を中心に一：韓国造園学会誌 Vol. 26 No.1, 83-95

3 ) 同掲書 1 )

Summary : Most of unused site are used as vegetable garden at inhabitant's disposal in Iisan new town in Korea. This study is aimed to clear the meaning and role of vegetable garden in unused site and to suggest possibility of setting of vegetable garden in new town. It based on interview survey with the users of vegetable garden in unused site. As the result of study, the using of vegetable garden has many effects in the aspect of healty and rest, mental, and social, with the role of utility. Moreover, because the users desire setting of vegetable garden as small size in reesidential district, it is necessary to set vegetable garden in new town in Korea. 